\title{
MULTI-CRITERIA OPTIMIZATION OF THE FIBER CONCRETES COMPOSITIONS OF RIGID PAVEMENT
}

\author{
S. Kroviakov ${ }^{1}$, A. Mishutin ${ }^{1}$, L. Chintea ${ }^{1}$ \\ ${ }^{1}$ Odessa State Academy of Civil Engineering and Architectur
}

\begin{abstract}
The experiment was carried out according to the optimal plan, which four factors of the composition of modified fiber concrete for rigid pavement were varied: amount of Portland cement, polypropylene fiber, metakaolin and polycarboxylate type additive. All concrete mixtures had equal mobility P2. Complex of experimental-statistical models describe the influence of factors on the properties of concrete is obtained. Selection of optimal compositions of fiber concrete of a rigid pavement was carried out using the obtained experimental-statistical models.

Graphical optimization method for "squares and squares" diagrams was used. The square in the coordinates "amount of metakaolin" - "amount of complex action additive Coral ExpertSuid-5" was used as a carrier in the construction of diagrams. These values of the mechanical characteristics of concrete were used as limitation criteria: compressive strength at the age of 3 and 28 days, flexural tensile strength, frost-resistance, abrasion. Frost-resistance and abrasion are the main indicators that ensure the durability of concrete for rigid pavement in typical operating conditions. The concrete prime cost indicator was used as an optimization criterion. 2 variants of concretes compositions of classes C30/35 and C32/40 with increased durability and high strength was chosen. The selected compositions of $\mathrm{C} 30 / 35$ class concretes have frost-resistance F350, flexural tensile strength 8.0-8.2 MPa, abrasion $0.38-0.39 \mathrm{~g} / \mathrm{cm}^{2}$, compressive strength at 3 days age $35 \mathrm{MPa}$ and strength at 28 days age $54 \mathrm{MPa}$. The selected compositions of C32/40 class concretes have frost-resistance F400, flexural tensile strength 8.5-8.6 MPa, abrasion $0.34 \mathrm{~g} / \mathrm{cm}^{2}$, compressive strength at 3 days age 38-39 $\mathrm{MPa}$ and strength at 28 days age 57-58 MPa. All four selected compositions have the amount of metakaolin 15$20 \mathrm{~kg} / \mathrm{m}^{3}$, polypropylene fiber $0.9-1.5 \mathrm{~kg} / \mathrm{m}^{3}$, polycarboxylate type additive Coral ExpertSuid-5 0.8$0.9 \%$ of the cement mass.
\end{abstract}

Keywords: experimental-statistical modeling, optimization, rigid pavement, fiber, strength, frostresistance, durability.

\section{БАГАТОКРИТЕРІАЛЬНА ОПТИМІЗАЦІЯ СКЛАДІВ ФІБРОБЕТОНІВ ЖОРСТКОГО ДОРОЖНЬОГО ПОКРИТТЯ}

\author{
Кровяков С. О. ${ }^{1}$, Мішутін А. В. ${ }^{1}$, Кінтя Л. ${ }^{1}$ \\ ${ }^{1}$ Одеська державна академія будівництва та архітектури
}

Анотація: За оптимальним планом проведено експеримент, у якому варіювалися чотири фактори складу модифікованих фібробетонів для жорстких дорожніх покриттів: кількість портландцементу, поліпропіленової фібри, метакаоліну і добавки полікарбоксилатного типу. Bci бетонні суміші мали рівну рухомість Р2. Отримано комплекс експериментальностатистичних моделей, які описують вплив факторів на властивості бетону. 3 використанням отриманих експериментально-статистичних моделей проведено вибір оптимальних складів фібробетонів жорсткого дорожнього покриття.

Застосовано графічний метод оптимізації за діаграмами типу «квадрати та квадраті». При побудові діаграм в якості несучого використовувався квадрат у координатах «кількість метакаоліну» - «кількість добавки комплексної дії Coral ExpertSuid-5». У якості критеріїв обмеження використовувалися такі значення фізико-механічних характеристик бетонів: міцність на стиск у віці 3 і 28 діб, міцність на розтяг при згині, морозостійкість, стиранність. Морозостійкість та стиранність є основними показниками, що забезпечують довговічність бетонів жорстких дорожніх покриттів в типових умовах експлуатації. У якості критерію 
оптимізації використовувався показник собівартості бетону. Обрано по 2 варіанти складів бетонів класів C30/35 і C32/40 з підвищеною довговічністю та високою ранньою міцністю. Обрані склади бетонів класу C30/35 мають морозостійкість F350, міцність на розтяг при згині

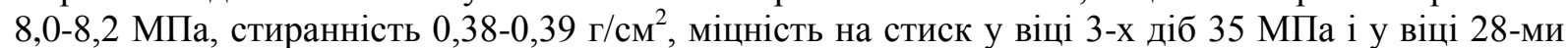
діб 54 МПа. Обрані склади бетонів класу C32/40 мають морозостійкість F400, міцність розтяг

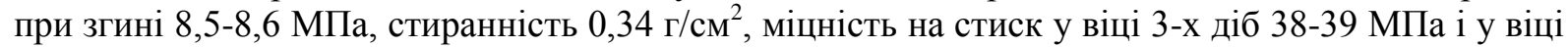
28-ми діб 57-58 МПа. Всі чотири обраних склади характеризуються кількістю метаколіну 15-20

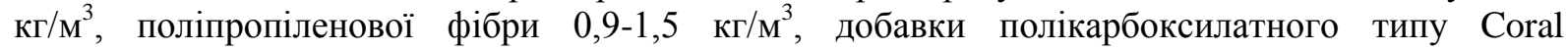
ExpertSuid-5 0,8-0,9\% від маси цементу.

Ключові слова: експериментально-статистичне моделювання, оптимізація, жорстке дорожнє покриття, фібра, міцність, морозостійкість, довговічність. 


\section{INTRODUCTION}

Rigid pavements are more durable than non-rigid asphalt pavement and they have many operational advantages, first of all, the absence of rutting. However, the repair of cementconcrete pavements is more difficult; therefore, the task of maximizing the durability of concrete on rigid pavement is relevance. In particular, this task is relevant for Ukraine, where cement-concrete roads have been actively built in recent years.

The durability of concretes used in pavements is mainly determined by frost-resistance and abrasion. Standardized quality indicators for rigid pavements are compressive strength and flexural tensile strength. The early strength of concrete is an important indicator in terms of the timing of opening traffic and facilitating technological operations. Accordingly, during using modifiers of various types and dispersed reinforcement to find the optimal compositions of concrete for rigid pavements, it is necessary to use the methods of multicriteria analysis of material properties.

\section{ANALYSIS OF LITERARY DATA AND RESOLVING THE PROBLEM}

The share of rigid pavements in the United States is 60\%, in Austria 46\%, Belgium 41\%, Germany $31 \%$, France $20 \%$, the Netherlands $15 \%$, Portugal 10\%, Spain, Italy, Canada, Switzerland and UK about 5\% [1]. In Ukraine and in the world more and more roads with cement-concrete pavement are being built. For example, in the Czech Republic, over the past 15 years, $65 \%$ of new roads were built from cement-concrete, and many such roads are also being built in Poland and Slovakia [2]. According to the "Program for the development of cement-concrete roads in Ukraine for 2021-2025," adopted by Ukravtodor, by 2025, it is planned to build and reconstruct about $2,900 \mathrm{~km}$ of national roads using rigid pavements.

In modern conditions, in the manufacture of concrete for rigid pavements, it is possible to achieve the required level of efficiency simultaneously with high durability and strength of the material only through the use of modifier additives [3]. Superplasticizers of the polycarboxylate type $[3,4]$ and pozzolanic additives, in particular metakaolin $[5,6]$, are some of the most effective modifiers today. Dispersed reinforcement is also an effective method for improving the mechanical properties of concrete, which determine its durability and performance $[7,8]$.

To search for rational compositions of concretes as multicomponent materials, it is advisable to use experimental planning methods [9]. Implementation of the experiment according to the optimal design allows obtaining adequate experimental-statistical models that show the relationship between the composition of the composite material and its properties [10]. By analyzing the complex of the obtained experimental-statistical (ES) models, it is possible to carry out multi-criteria optimization of the composition of concrete, including the composition of concrete of rigid pavements.

\section{PURPOSE AND TASKS OF THE STADY}

The purpose of this study is to select the optimal compositions of rigid pavement fiber concrete of C30/35 and C32/40 classes with increased durability and high early strength. Concretes at a project age of 28 days must meet to their class in compressive strength, provide increased flexural tensile strength, frost-resistance, wear-resistance (low abrasion) and early strength. At the same time, the prime cost of the selected compositions should be minimal, which is important given the large amount of concrete works in road construction. 


\section{BASIC RESULTS}

In accordance with the 18-point optimal plan, a 4-factor experiment was carried out, in which the following factors of the composition of fiber concrete of rigid pavements were varied [11]:

- X1, amount of Portland cement (CEM II/A-S 42.5), from 400 to $500 \mathrm{~kg} / \mathrm{m}^{3}$;

- X2, amount of polypropylene fiber (length $12 \mathrm{~mm}$, diameter $20 \mu \mathrm{m}$ ), from 0 to $2 \mathrm{~kg} / \mathrm{m}^{3}$;

- X3, amount of metakaolin, from 0 to $30 \mathrm{~kg} / \mathrm{m}^{3}$;

- X4, amount of polycarboxylate additives of complex action (superplasticizer and accelerator) Coral ExpertSuid-5, from 0.6 to $1 \%$ by weight of cement.

All the mixtures of tested fiber concretes had equal mobility P2 (slump from 6 to $8 \mathrm{~cm}$ ), which was achieved by varying the amount of water.

Selection of the optimal compositions of fiber concrete of rigid pavements was carried out using a set of obtained ES-models. These models describe the effect of the composition on the corresponding properties of the composite:

- compressive strength at the age of 3 days:

$$
\begin{aligned}
& \mathrm{f}_{\text {ck.cube. } 3}(\mathrm{MPa})=40.9+5.8 \mathrm{x}_{1}-1.7 \mathrm{x}_{1}^{2}+0.8 \mathrm{x}_{1} \mathrm{x}_{2} \pm 0 \mathrm{x}_{1} \mathrm{x}_{3} \pm 0 \mathrm{x}_{1} \mathrm{x}_{4} \\
& -0.4 \mathrm{x}_{2}+0.9 \mathrm{x}_{2}^{2} \quad \pm 0 \mathrm{x}_{2} \mathrm{x}_{3}-0.6 \mathrm{x}_{2} \mathrm{x}_{4} \\
& +2.1 \mathrm{x}_{3}-0.8 \mathrm{x}_{3}^{2}+1.0 \mathrm{x}_{3} \mathrm{x}_{4} \\
& +3.0 \mathrm{x}_{4}-1.1 \mathrm{x}_{4}^{2}
\end{aligned}
$$

- compressive strength at the project age:

$$
\begin{array}{rlr}
\mathrm{f}_{\text {ck. cube }}(\mathrm{MPa})=59.4 & +5.9 \mathrm{x}_{1}-2.4 \mathrm{x}_{1}^{2}+1.1 \mathrm{x}_{1} \mathrm{x}_{2} \pm 0 \mathrm{x}_{1} \mathrm{x}_{3}+1.1 \mathrm{x}_{1} \mathrm{x}_{4} \\
& -2.0 \mathrm{x}_{2}+2.4 \mathrm{x}_{2}^{2} \quad \pm 0 \mathrm{x}_{2} \mathrm{x}_{3}-1.0 \mathrm{x}_{2} \mathrm{x}_{4} \\
& +1.6 \mathrm{x}_{3}-3.1 \mathrm{x}_{3}^{2} & \pm 0 \mathrm{x}_{3} \mathrm{x}_{4} \\
& +1.5 \mathrm{x}_{4}-1.9 \mathrm{x}_{4}^{2} &
\end{array}
$$

- flexural tensile strength at the project age:

$$
\begin{array}{rlr}
\mathrm{f}_{\text {ctk }}(\mathrm{MPa})=8.30 & +0.61 \mathrm{x}_{1}-0.22 \mathrm{x}_{1}^{2}+0.07 \mathrm{x}_{1} \mathrm{x}_{2} \pm 0 \mathrm{x}_{1} \mathrm{x}_{3}+0.10 \mathrm{x}_{1} \mathrm{x}_{4} \\
& +0.32 \mathrm{x}_{2} \pm 0 \mathrm{x}_{2}^{2} & +0.09 \mathrm{x}_{2} \mathrm{x}_{3}-0.13 \mathrm{x}_{2} \mathrm{x}_{4} \\
& +0.05 \mathrm{x}_{3}-0.17 \mathrm{x}_{3}^{2} & +0.05 \mathrm{x}_{3} \mathrm{x}_{4} \\
& +0.11 \mathrm{x}_{4}+0.09 \mathrm{x}_{4}^{2} &
\end{array}
$$

- frost-resistance:

$$
\begin{array}{rlr}
\mathrm{F}(\text { cycles })=393 & +60 \mathrm{x}_{1} \pm 0 \mathrm{x}_{1}^{2}+8 \mathrm{x}_{1} \mathrm{x}_{2} \pm 0 \mathrm{x}_{1} \mathrm{x}_{3} \pm 0 \mathrm{x}_{1} \mathrm{x}_{4} \\
+ & 23 \mathrm{x}_{2}-14 \mathrm{x}_{2}^{2} & -10 \mathrm{x}_{2} \mathrm{x}_{3} \pm 0 \mathrm{x}_{2} \mathrm{x}_{4} \\
+ & 7 \mathrm{x}_{3}-29 \mathrm{x}_{3}^{2} & +7 \mathrm{x}_{3} \mathrm{x}_{4} \\
+19 \mathrm{x}_{4}-23 \mathrm{x}_{4}^{2} &
\end{array}
$$

- abrasion:

$$
\begin{array}{ccc}
\mathrm{G}\left(\mathrm{g} / \mathrm{cm}^{2}\right)=0.350-0.036 \mathrm{x}_{1}+0.020 \mathrm{x}_{1}^{2}-0.016 \mathrm{x}_{1} \mathrm{x}_{2}-0.008 \mathrm{x}_{1} \mathrm{x}_{3} & \pm 0 \mathrm{x}_{1} \mathrm{x}_{4} \\
-0.056 \mathrm{x}_{2}+0.030 \mathrm{x}_{2}^{2} & \pm 0 \mathrm{x}_{2} \mathrm{x}_{3} & \pm 0 \mathrm{x}_{2} \mathrm{x}_{4} \\
-0.006 \mathrm{x}_{3}+0.012 \mathrm{x}_{3}^{2} & & \pm 0 \mathrm{x}_{3} \mathrm{x}_{4} \\
-0.018 \mathrm{x}_{4}+0.022 \mathrm{x}_{4}^{2} & &
\end{array}
$$


- prime cost indicator calculated in the prices of March 2020:

$$
\begin{array}{rlr}
\operatorname{Cost}\left(\mathrm{UAH} / \mathrm{m}^{3}\right)=1886.02 & +112.21 \mathrm{x}_{1}-0.54 \mathrm{x}_{1}^{2} \pm 0 \mathrm{x}_{1} \mathrm{x}_{2}-0.31 \mathrm{x}_{1} \mathrm{x}_{3}+1.91 \mathrm{x}_{1} \mathrm{x}_{4} \\
& +47.49 \mathrm{x}_{2} \pm 0 \mathrm{x}_{2}^{2} & -0.53 \mathrm{x}_{2} \mathrm{x}_{3}+0.38 \mathrm{x}_{2} \mathrm{x}_{4} \\
& +128.62 \mathrm{x}_{3}-0.85 \mathrm{x}_{3}^{2} & -0.30 \mathrm{x}_{3} \mathrm{x}_{4} \\
& +17.43 \mathrm{x}_{4}+0.32 \mathrm{x}_{4}^{2} &
\end{array}
$$

Selection was carried out by a graphical method on diagrams of the "squares on a square" type [10]. Selection of compositions of fiber concrete with two different levels of requirements for the characteristics of the material was carried out. In the first version (concretes of class $\mathrm{C} 30 / 35$ ), the following values of the mechanical characteristics of concretes were used as limitation criteria:

- compressive strength $\mathrm{f}_{\text {ck.cube }} \geq 50 \mathrm{MPa}$. Such strength is ensured by the class of concrete $\mathrm{C} 30 / 35$ at the most common level of the coefficient of variation for concrete plants in Ukraine. This allows the use of concrete on roads of category I-b (B35, M500 according to the requirements of DBN V.2.3-4:2015). Isolines $\mathrm{f}_{\text {ck.cube }}=50 \mathrm{MPa}$ are plotted according to the ES-model (2) and are shown in red in the diagrams;

- flexural tensile strength $\mathrm{f}_{\mathrm{ctk}} \geq 8 \mathrm{MPa}$. Such tensile strength ensures the quality of work of the material in the structure of the pavement and largely provides the durability of concrete under high loads. Isolines $\mathrm{f}_{\text {ctk }}=8 \mathrm{MPa}$ are plotted according to the ES-model (3) and are shown in green in the diagrams;

- frost-resistance $\geq$ F350. Such level of frost-resistance ensures high durability of concrete during the operation of rigid pavements in typical climatic conditions of Ukraine. Isolines F350 are plotted according to the ES-model (4) and are shown in blue in the diagrams;

- abrasion $\mathrm{G} \leq 0.40 \mathrm{~g} / \mathrm{cm}^{2}$. This level of abrasion (no more than $0.40 \mathrm{~g} / \mathrm{cm}^{2}$ ) provides high wear resistance of concrete, respectively, the durability of concrete in conditions of heavy traffic. Isolines $\mathrm{G}=0.40 \mathrm{~g} / \mathrm{cm}^{2}$ are plotted according to the ES-model (5) and are shown in gray in the diagrams;

- compressive strength at the age of 3 days $\mathrm{f}_{\text {ck.cube. } 3} \geq 35 \mathrm{MPa}$. Such a high level of early strength makes it possible to start operating roads earlier and facilitates subsequent technological operations during the construction process. Isolines $\mathrm{f}_{\text {ck.cube. } 3}=35 \mathrm{MPa}$ are plotted according to the ES-model (1) and are shown in purple in the diagrams.

As an optimization criterion [10], the indicator of the prime cost of concrete $\left(\mathrm{UAH} / \mathrm{m}^{3}\right)$, calculated in prices of March 2020, was used. Isolines of the prime cost of concrete are plotted according to the ES-model (6) are shown in brown in the diagrams.

A square in coordinates $\mathrm{X}_{3}$ (amount of metakaolin) $-\mathrm{X}_{4}$ (amount of a complex action additive Coral ExpertSuid-5) was used as a carrier when constructing diagrams of the "squares on a square" type. Diagrams in the field of a bearing square at various levels of factors $\mathrm{x}_{3}-\mathrm{x}_{4}$ reflect the effect of the amount of Portland cement and polypropylene fiber. The diagrams take into account the fact that for a significant part of the mechanical characteristics the best indicators (the highest strength, the highest frost-resistance, the lowest abrasion, etc.) were observed for compositions with the amount of Metakaolin $18-20 \mathrm{~kg} / \mathrm{m}^{3}$ and with the amount of additive Coral ExpertSuid-5 about 0,9\% [11]. Accordingly, in the field of the carrier square, not 9 , but 16 diagrams of the influence of factors $\mathrm{x}_{1}-\mathrm{x}_{2}$ are shown for more accurate optimization (Fig. 1). Diagrams in coordinates $x_{3}=+0.333\left(20 \mathrm{~kg} / \mathrm{m}^{3}\right.$ Metakaolin) and $\mathrm{x}_{4}=0.5(0.9 \%$ additive $)$ were added to the diagrams in the main $(-1,0,1)$ coordinates of factors.

Areas of the diagrams that did not meet the specified limitation criteria were shaded with the appropriate color. In the unshaded areas, that is, when all the established quality criteria 
are met, two optimal compositions were selected. These compositions (coordinates) are marked with stars with corresponding numbers in Fig. 1.

In the second option for choosing the optimal compositions (concretes of C32/40 class), the following values of the mechanical characteristics of concretes were used as limitation criteria:

- compressive strength $\mathrm{f}_{\text {ck.cube }} \geq 55 \mathrm{MPa}$, which provides the required class of concrete on roads of category I-a (B40, M550 according to the requirements of DBN V.2.3-4:2015) and allows the use of concrete on roads with the highest loads. According to [12], preference should always be given to pavements made of high-strength concrete of B40..B60 classes, which ensures the durability of new roads during construction. Isolines $f_{\text {ck. } \text {.cube }}=55 \mathrm{MPa}$ are shown in red in the diagrams;

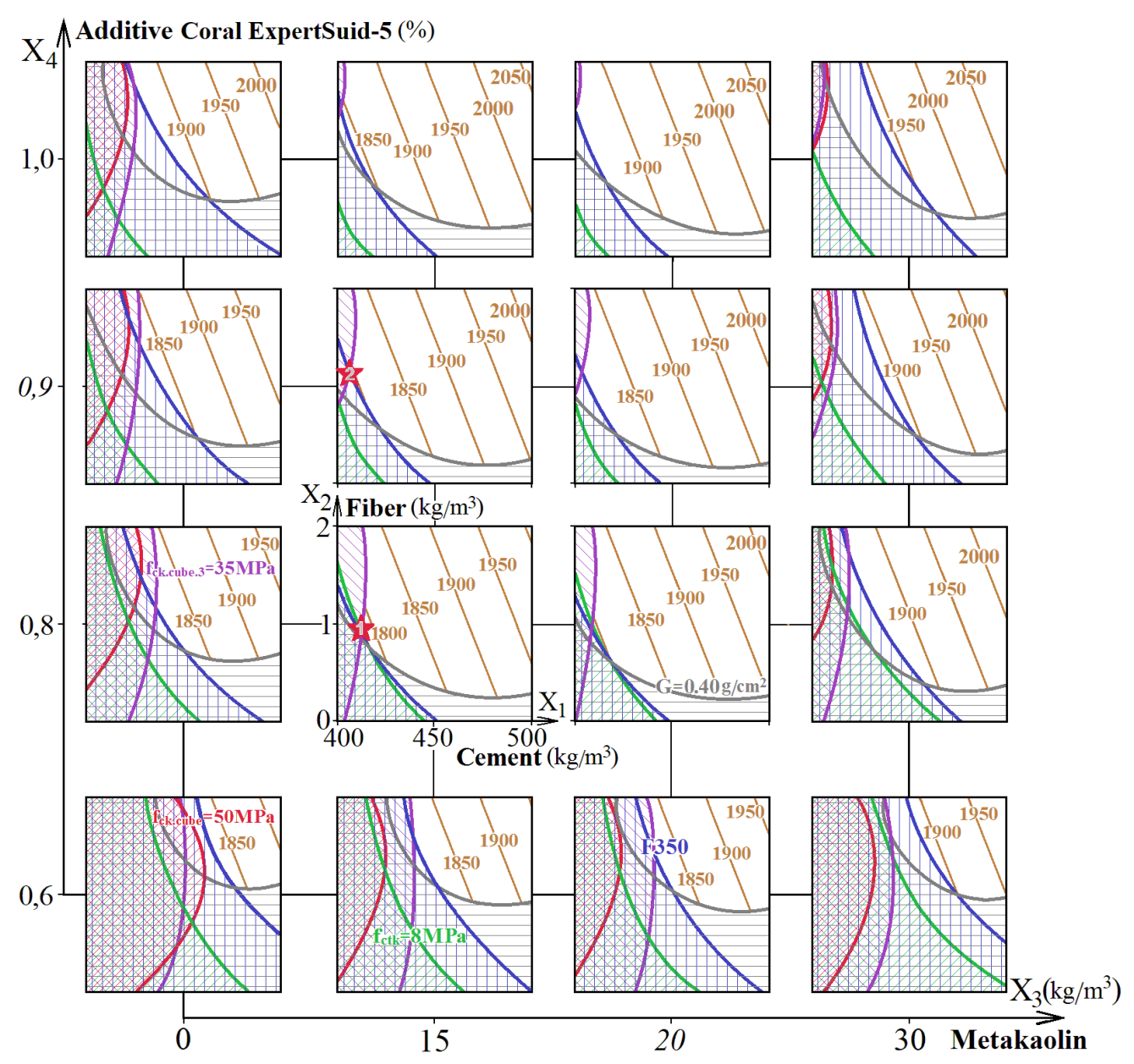

Fig. 1. Selection of the optimal compositions of rigid pavement fiber concrete of C30/35 class

- flexural tensile strength $\mathrm{f}_{\mathrm{ctk}} \geq 8.5 \mathrm{MPa}$, which is $0.5 \mathrm{MPa}$ higher than was specified as a limitation criterion when choosing concretes of C30/35 class. This ensures a higher quality and durability of the material in the construction of the pavement compared to the C30/35 class concretes. Isolines $\mathrm{f}_{\mathrm{ctk}}=8.5 \mathrm{MPa}$ are shown in green in the diagrams;

- frost-resistance $\geq$ F400, which is 50 cycles higher than was specified as a limitation criterion when choosing concretes of $\mathrm{C} 30 / 35$ class. This ensures even greater durability of concrete during operation in Ukrainians climatic conditions. Isolines F400 are shown in blue in the diagrams;

- abrasion $\mathrm{G} \leq 0,350.35 \mathrm{~g} / \mathrm{cm}^{2}$, which is $0.05 \mathrm{~g} / \mathrm{cm}^{2}$ lower than was specified as a limitation criterion when choosing concretes of C30/35 class. Such abrasion provides a higher 
wear resistance of the pavement in conditions of heavy traffic. Isolines $G=0.35 \mathrm{~g} / \mathrm{cm}^{2}$ are shown in gray in the diagrams;

- compressive strength at the age of 3 days $\mathrm{f}_{\text {ck.cube. } 3} \geq 35 \mathrm{MPa}$, which is similar to the limitation when choosing compositions of concretes of C30/35 class. This strength also makes it possible to start the operation of roads earlier and facilitates the implementation of subsequent technological operations. Isolines $\mathrm{f}_{\text {ck.cube. } 3}=35 \mathrm{MPa}$ are shown in purple in the diagrams.

The isolines in Fig. 2 were plotted using the same EC-models, which were used to plot similar isolines in Fig. 1. These isolines similarly reflect the change in all investigated properties of concrete.

The two optimal concrete compositions were selected in the unshaded areas in Fig. 2, that is, when the levels of all assigned quality criteria are met. Composition coordinates are marked with stars with corresponding numbers, which is similar to Fig. 1.

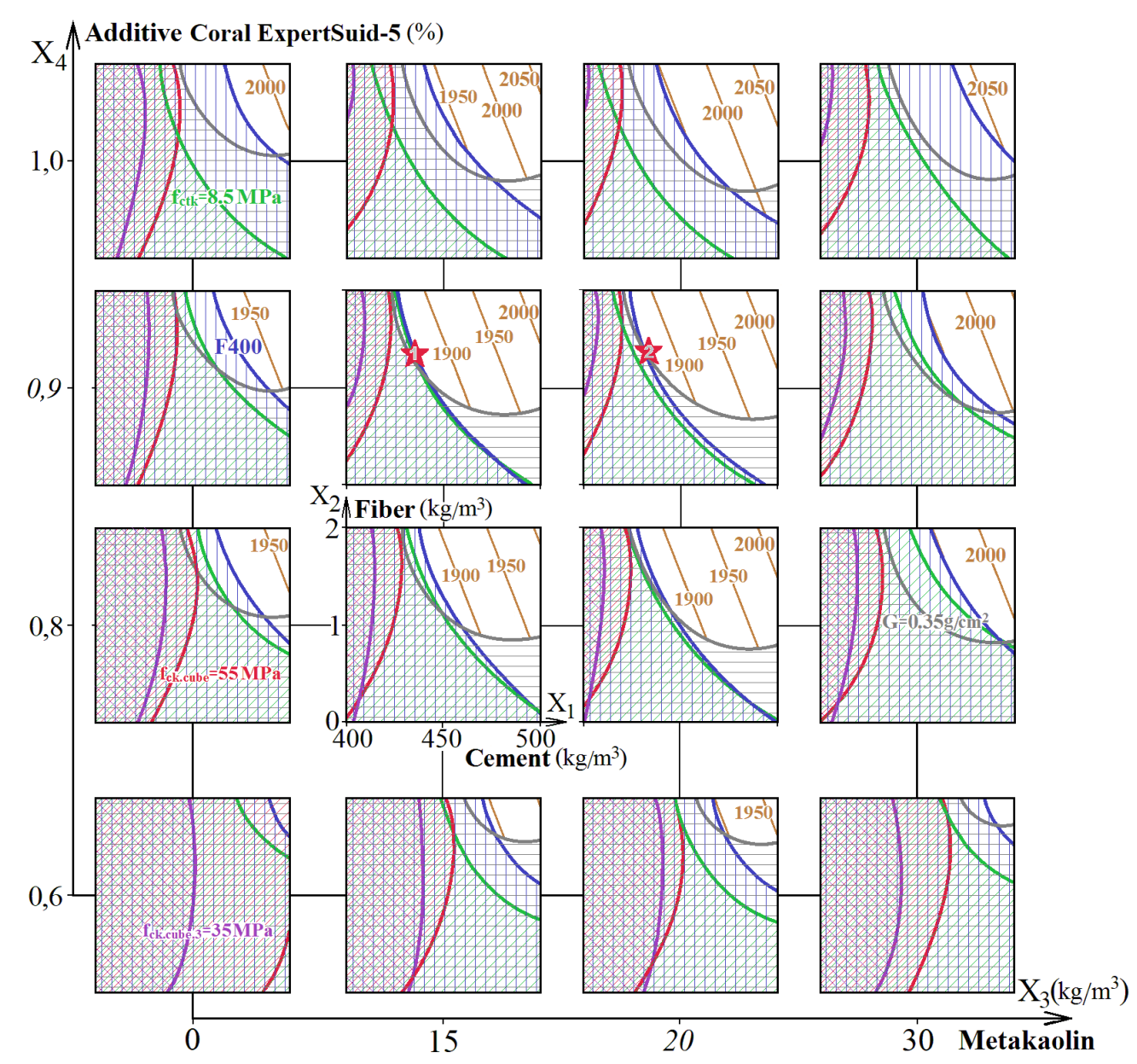

Fig. 2. Selection of the optimal compositions of rigid pavement fiber concrete of C32/40 class

\section{DISCUSSION OF THE RESULTS OF THE STUDY}

As mentioned earlier, two optimal compositions of C30/35 class fiber concretes were selected. These compositions are marked with stars with corresponding numbers in Fig. 1.

Composition No.1 (C30/35) is characterized by the lowest prime cost $\left(1790 \mathrm{UAH} / \mathrm{m}^{3}\right)$ and provides the necessary level for all quality criteria of concrete. The point of this composition in a factor space has the coordinates: $\mathrm{x}_{1}=-0.6, \mathrm{x}_{2}=-0.1, \mathrm{x}_{3}=0, \mathrm{x}_{4}=0$.

Composition No.2 (C30/35) has a prime cost $1800 \mathrm{UAH} / \mathrm{m} 3$, which is only $0.6 \%$ more than the prime cost of composition No. 1. At the same time, concrete of composition No.2 in 
comparison with composition No.1 has a slightly higher flexural tensile strength and less abrasion. The point of this composition in a factor space has the coordinates: $\mathrm{x}_{1}=-0.7$, $\mathrm{x}_{2}=0.1, \mathrm{x}_{3}=0, \mathrm{x}_{4}=0.5$.

Also, two optimal compositions of C32/40 class fiber concretes were selected. These compositions are marked with stars with corresponding numbers in Fig. 2.

Composition No.1 (C32/40) is characterized by the lowest prime cost $\left(1860 \mathrm{UAH} / \mathrm{m}^{3}\right)$ and provides the necessary level for all quality criteria of concrete. The point of this composition in a factor space has the coordinates: $\mathrm{x}_{1}=-0.3, \mathrm{x}_{2}=0.4, \mathrm{x}_{3}=0, \mathrm{x}_{4}=0.5$.

Composition No.2 (C32/40) has a prime cost of $1865 \mathrm{UAH} / \mathrm{m} 3$, which practically does not differ from the prime cost of composition No.1. At the same time, the composition No. 2 has a slightly higher compressive strength and flexural tensile strength compared to the composition No.1. The difference between the indicators of the mechanical properties of the compositions No.1 and No.2 is within the limits of the experimental accuracy. But for composition No. 2, this difference ensures the achievement of the required level of strength with a greater probability. The point of composition No.2 in a factor space has the coordinates: $\mathrm{x}_{1}=-0.35, \mathrm{x}_{2}=0.5, \mathrm{x}_{3}=0.33, \mathrm{x}_{4}=0.5$.

The content of the components of the mixture for all selected compositions of concretes C30/35 and C32/40 classes and the calculated mechanical properties of concretes are shown in Table 1.

Table 1

Selected optimal compositions of fiber concrete and their mechanical characteristics.

\begin{tabular}{|c|c|c|}
\hline $\begin{array}{c}\text { No. } \\
\text { composition }\end{array}$ & Composition of concrete & Mechanical characteristics \\
\hline $\begin{array}{l}\text { C30/35, } \\
\text { composition } \\
\text { No.1 }\end{array}$ & $\begin{array}{l}\text { Cement }-420 \mathrm{~kg} / \mathrm{m}^{3} \\
\text { Crushed stone }-1127 \mathrm{~kg} / \mathrm{m}^{3} \\
\text { Sand }-676 \mathrm{~kg} / \mathrm{m}^{3} \\
\text { Metakaolin }-15 \mathrm{~kg} / \mathrm{m}^{3} \\
\text { Fiber }-0.9 \mathrm{~kg} / \mathrm{m}^{3} \\
\text { Additive Coral }-3.36 \mathrm{~kg} / \mathrm{m}^{3} \\
\text { Water }-174 \mathrm{l} / \mathrm{m}^{3}\end{array}$ & $\begin{array}{l}\text { Compressive strength } \mathrm{f}_{\text {ck.cube }}=54 \mathrm{MPa} \\
\text { Flexural tensile strength } \mathrm{f}_{\text {ctk }}=8 \mathrm{MPa} \\
\text { Frost-resistance } \mathrm{F} 350 \\
\text { Abrasion } \mathrm{G}=0.395 \mathrm{~g} / \mathrm{cm}^{2} \\
\text { Compressive strength at the age of } 3 \text { days } \mathrm{f}_{\text {ck.cube. } 3}=35 \\
\mathrm{MPa} \\
\text { Prime cost }-1790 \mathrm{UAH} / \mathrm{m}^{3}\end{array}$ \\
\hline $\begin{array}{l}\text { C30/35, } \\
\text { composition } \\
\text { No.2 }\end{array}$ & $\begin{array}{l}\text { Cement }-415 \mathrm{~kg} / \mathrm{m}^{3} \\
\text { Crushed stone }-1131 \mathrm{~kg} / \mathrm{m}^{3} \\
\text { Sand }-686 \mathrm{~kg} / \mathrm{m}^{3} \\
\text { Metakaolin }-15 \mathrm{~kg} / \mathrm{m}^{3} \\
\text { Fiber }-1.1 \mathrm{~kg} / \mathrm{m}^{3} \\
\text { Additive Coral }-3.74 \mathrm{~kg} / \mathrm{m}^{3} \\
\text { Water }-169 \mathrm{l} / \mathrm{m}^{3}\end{array}$ & $\begin{array}{l}\text { Compressive strength } \mathrm{f}_{\text {ck.cube }}=54 \mathrm{MPa} \\
\text { Flexural tensile strength } \mathrm{f}_{\text {ctk }}=8.2 \mathrm{MPa} \\
\text { Frost-resistance } \mathrm{F} 350 \\
\text { Abrasion } \mathrm{G}=0.38 \mathrm{~g} / \mathrm{cm}^{2} \\
\text { Compressive strength at the age of } 3 \text { days } \mathrm{f}_{\text {ck.cube. } 3}=35 \\
\mathrm{MPa} \\
\text { Prime cost }-1800 \mathrm{UAH} / \mathrm{m}^{3}\end{array}$ \\
\hline $\begin{array}{l}\text { C32/40, } \\
\text { composition } \\
\text { No.1 }\end{array}$ & $\begin{array}{l}\text { Cement }-435 \mathrm{~kg} / \mathrm{m}^{3} \\
\text { Crushed stone }-1124 \mathrm{~kg} / \mathrm{m}^{3} \\
\text { Sand }-669 \mathrm{~kg} / \mathrm{m}^{3} \\
\text { Metakaolin }-15 \mathrm{~kg} / \mathrm{m}^{3} \\
\text { Fiber }-1.4 \mathrm{~kg} / \mathrm{m}^{3} \\
\text { Additive Coral }-3.92 \mathrm{~kg} / \mathrm{m}^{3} \\
\text { Water }-175 \mathrm{l} / \mathrm{m}^{3}\end{array}$ & $\begin{array}{l}\text { Compressive strength } \mathrm{f}_{\text {ck.cube }}=57 \mathrm{MPa} \\
\text { Flexural tensile strength } \mathrm{f}_{\text {ctk }}=8.5 \mathrm{MPa} \\
\text { Frost-resistance } \mathrm{F} 400 \\
\text { Abrasion } \mathrm{G}=0.34 \mathrm{~g} / \mathrm{cm}^{2} \\
\text { Compressive strength at the age of } 3 \text { days } \mathrm{f}_{\text {ck.cube. } 3}=38 \\
\mathrm{MPa} \\
\text { Prime cost }-1860 \mathrm{UAH} / \mathrm{m}^{3}\end{array}$ \\
\hline $\begin{array}{l}\text { C32/40, } \\
\text { composition } \\
\text { No.2 }\end{array}$ & $\begin{array}{l}\text { Cement }-433 \mathrm{~kg} / \mathrm{m}^{3} \\
\text { Crushed stone }-1124 \mathrm{~kg} / \mathrm{m}^{3} \\
\text { Sand }-665 \mathrm{~kg} / \mathrm{m}^{3} \\
\text { Metakaolin }-20 \mathrm{~kg} / \mathrm{m}^{3} \\
\text { Fiber }-1.5 \mathrm{~kg} / \mathrm{m}^{3} \\
\text { Additive Coral }-3.90 \mathrm{~kg} / \mathrm{m}^{3} \\
\text { Water }-1761 / \mathrm{m}^{3}\end{array}$ & $\begin{array}{l}\text { Compressive strength } \mathrm{f}_{\text {ck.cube }}=58 \mathrm{MPa} \\
\text { Flexural tensile strength } \mathrm{f}_{\text {ctk }}=8.6 \mathrm{MPa} \\
\text { Frost-resistance } \mathrm{F} 400 \\
\text { Abrasion } \mathrm{G}=0.34 \mathrm{~g} / \mathrm{cm}^{2} \\
\text { Compressive strength at the age of } 3 \text { days } \mathrm{f}_{\text {ck.cube. } 3}=39 \\
\mathrm{MPa} \\
\text { Prime cost }-1865 \mathrm{UAH} / \mathrm{m}^{3}\end{array}$ \\
\hline
\end{tabular}




\section{CONCLUSIONS}

Thus, the multicriteria optimization of the compositions of fiber concrete of a rigid pavement was carried out using the obtained complex of EC-models. Optimal compositions of fiber concrete of rigid pavements of C30/35 and C32/40 classes with increased durability under typical operating conditions and high early strength are selected taking into account the cost price.

\section{References}

1. Hall, K., Dawood, D., Vanikar, S. and other (2007). Long-life Concrete Pavements in Europe and Canada. Report No. FHWA-PL-07-027. American Trade Initiatives.

2. Śliwiński, J., Hager, I., Tracz, T. and other (2010). New generation cement concretes. Ideas, design, technology and applications. Cracow: Cracow University of Technology.

3. Sobko, Y. M., Shevchuk, G. Y., Topylko, N. I., $\quad$ Novyts'kyy, Y. L. $\quad$ (2018). Dorozhni tsementobetony na osnovi modyfikovanykh dobavok novoyi heneratsiyi. [Road cement concretes based on modified additives of new generation] Visnyk Natsional'noho universytetu "L'vivs'ka politekhnika". Seriya: Teoriya i praktyka budivnytstva [Lviv Polytechnic National University]. L'viv: Vydavnytstvo L'vivs'koyi politekhniky. 888. 133-137. [in Ukranian].

4. Liu, J., Yu, C., Ran, Q., Yang, Y. (2019). Recent advance of chemical admixtures in concrete. Cement and Concrete Research. Vol. 124. 105834.

5. Kryzhanovskiy, V. O., Kroviakov, S. O. Zavoloka, M. V. (2021). Influence of metakaolin on properties of concrete modified with polycarboxylate admixture for rigid pavement repair. Bulletin of odessa state academy of civil engineering and architecture. 82. 90-97.

6. Salimi, J., Ramezanianpour, A. M., Moradi, M. J. (2020). Studying the effect of low reactivity metakaolin on free and restrained shrinkage of high performance concrete. Journal of Building Engineering. Vol. 28:101053.

7. Liu, H., Wang, N. (2020). Computer model and analysis on pavement performance and pavement structure of polypropylene fibre material concrete. Journal of Physics: Conference Series. Vol. 1578. Issue 1. No. 012057.

8. Kroviakov, S., Kryzhanovskyi, V., Zavoloka, M. (2021) Steel fibrous concrete with high-early strength for rigid pavements repair. IOP Conf. Series: Materials Science and Engineering. 1162. No. 012008 .

9. Jeff Wu, C. F., Hamada, M. S. (2009). Experiments: Planning, Analysis, and Optimization. 2d ed. Wiley \& Sons. 552.

10.Lyashenko, T. V., Voznesenskiy, V. A. (2017) Metodologiya retsepturno-tekhnologicheskikh poley $v$ komp'yuternom stroitel'nom materialovedenii. [Methodology of recipe-technological fields in computer building materials science]. Odessa: Astroprint. [in Russian].

11.Mishutin, A., Kos, Z., Grynyova, I., Chintea, L. (2021) Durability of modified fiber concrete for rigid pavements. Croatian regional development journal. Vol. 2. No. 1. 35-46.

12.Hamelyak, I. P., Korets'kyy, A. S., Korets'kyy, S. S. (2013) Pro neobkhidnist' budivnytstva v Ukrayini avtomobil'nykh dorih iz tsementobetonnym pokryttyam. [About necessity of construction in Ukraine of highways with a cement-concrete covering]. Avtoshlyakhovyk Ukrayiny. №5 (235). 24-31. [in Ukranian].

\section{Література}

1. Hall K., Dawood D., Vanikar S. and other. Long-life Concrete Pavements in Europe and Canada Report No. FHWA-PL-07-027, American Trade Initiatives. 2007. 69 p.

2. Śliwiński J., Hager I., Tracz T. and other. New generation cement concretes. Ideas, design, technology and applications Cracow: Cracow University of Technology. 2010. 189 p.

3. Собко Ю. М., Шевчук Г. Я., Топилко Н. І., Новицький Ю. Л. Дорожні цементобетони на основі модифікованих добавок нової генерації. Вісник Національного університету “Львівська політехніка". Серія: Теорія і практика будівництва. Львів: Видавництво Львівської політехніки, 2018. № 888. С. 133-137. 
4. Liu H., Wang N. Computer model and analysis on pavement performance and pavement structure of polypropylene fibre material concrete. Journal of Physics: Conference Series. 2020. V. 1578. Issue 1. No. 012057.

5. Kryzhanovskiy V. O., Kroviakov S. O. Zavoloka M. V. Influence of metakaolin on properties of concrete modified with polycarboxylate admixture for rigid pavement repair. Вісник Одеської державної академії будівництва та архітектури, 2021. №82. С. 90-97

6. Salimi J., Ramezanianpour A.M., Moradi M.J. Studying the effect of low reactivity metakaolin on free and restrained shrinkage of high performance concrete. Journal of Building Engineering. 2020. V. 28:101053.

7. Liu H., Wang N. Computer model and analysis on pavement performance and pavement structure of polypropylene fibre material concrete. Journal of Physics: Conference Series. 2020. V. 1578. Issue 1. No. 012057.

8. Kroviakov S., Kryzhanovskyi V., Zavoloka M. Steel fibrous concrete with high-early strength for rigid pavements repair. IOP Conf. Series: Materials Science and Engineering. 2021. 1162. No. 012008

9. Jeff Wu C. F., Hamada M.S. Experiments: Planning, Analysis, and Optimization. $2 d$ ed., Wiley \& Sons, 2009. $552 \mathrm{p}$.

10.Ляшенко Т. В., Вознесенский В. А. Методология рецептурно-технологических полей в компьютерном строительном материаловедении. Одесса: Астропринт, 2017. 168 с.

11. Mishutin A., Kos Z., Grynyova I., Chintea L. Durability of modified fiber concrete for rigid pavements. Croatian regional development journal. 2021. Vol. 2. No. 1. pp. 35-46.

12.Гамеляк І. П., Корецький А. С., Корецький С. С. Про необхідність будівництва в Україні автомобільних доріг із цементобетонним покриттям. Автошляховик України, 2013. №5 (235). C. 24-31.

\author{
Kroviakov Sergii \\ Odessa State Academy of Civil Engineering and Architecture \\ Doctor of Technical Sciences, associate professor \\ Didrihsona str.,4 Odessa, Ukraine, 65029 \\ skrovyakov@ukr.net \\ ORCID: 0000-0002-0800-0123 \\ Mishutin Andrey \\ Odessa State Academy of Civil Engineering and Architecture \\ Doctor of Technical Sciences, professor \\ Didrihsona str.,4 Odessa, Ukraine, 65029 \\ mishutin52@ukr.net \\ ORCID: 0000-0001-9512-6084 \\ Chintea Lucia \\ Odessa State Academy of Civil Engineering and Architecture \\ Graduate student \\ Didrihsona str.,4 Odessa, Ukraine, 65029 \\ chintea.lucia@gmail.com \\ ORCID: 0000-0001-7519-4987
}

For references:

Kroviakov S., Mishutin A., Chintea L. (2021). Multi-criteria optimization of the fiber concretes compositionS of rigid pavement. Mechanics and Mathematical Methods. 3 (1). 62 - 71

Для посилань:

Кровяков С. О., Мішутін А. В., Кінтя Л. Багатокритеріальна оптимізація складів фібробетонів жорсткого дорожнього покриття. Механіка та математичні методи, 2021. Т. 3. №. 1. С. 62-71. 